\title{
УДК 613.6.008.4:622-057.5
}

\section{УАОСКОНАЛЕННЯ ПОРЯАКУ ОUНКИ Й ПРОФIМАКТИКИ ВПАИВУ УМОВ ПРАШ

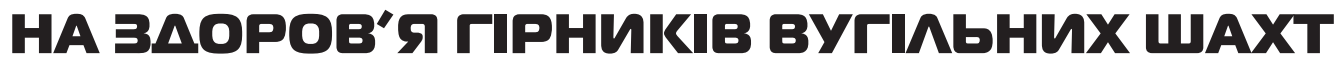

\author{
Передерій Г. С.', ^астков А. О.', Ветров С. Ф.' , Партас О. В.' \\ 'Аонешький національний медичний університет імені М. Горького \\ ${ }^{2} \Delta$ онешька обласна санітарно-епісеміологічна станшія
}

Визначено відмінності в умовах праці гірників вугільних шахт із пологими й крутими пластами. Доведено, що вони зумовлені технологіями, що застосовуються, і глибиною розробки вугільних горизонтів. Установлено, що структура та рівні професійних ризиків і захворюваності відбивають ступінь шкідливості та важкості праці. Представлені результати структуризації гірників за рівнями шкідливого впливу умов праці. Наведений порядок отримання й шляхи використання даних структуризації для планування заходів збереження професійного здоров'я й розрахунку кошторису шодо їх здійснення.

Ключові слова: гірники, професійне здоров'я, профілактика

\section{Вступ}

31 січня 2011 року в Україні розпочалася державна реформа охорони здоров'я. Мета реформи полягає в підвищенні якості надання медичної допо моги населенню через зміну мережі закладів охоро ни здоров'я, оптимізацію шляхів використання в галузі фінансових ресурсів, удосконалення системи контролю якості наданих послуг. Реальне вирішення цих питань неможливо без визначення дійсних потреб населення в медико-соціальних послугах у межах окремих адміністративно-територіальних утворень і України в цілому. Як модель отримання санітарно-гігієнічних та медичних даних стосовно оцінки професійного здоров'я населення і подальшого їхнього використання в плануванні заходів щодо збереження здоров'я в медицині праці з успіхом використовується традиційна система попередніх та періодичних медичних оглядів і диспансеризації працюючих у шкідливих умовах, що спирається на тривалий досвід застосування в ризиконебезпечних галузях промисловості та сільського господарства і з успіхом пройшла випробування часом. За останній період можливості проведення санітарно-гігієнічного моніторингу умов праці та стану професійного здоров'я працюючих і адміністративного управління процесами профілактики негативного впливу на організм шкідливих і небезпечних факторів виробничого середовища і трудового процесу суттево розширилися. Спираючись на сучасні телекомунікаційні інновації, розроблено медичну технологію створення баз даних про умови праці й стан здоров'я працюючих [1,2], обгрунто- вано пропозиції щодо організації інфраструктури i порядку проведення санітарно-гігіенічного моніторингу [3-5], апробовано автоматизовану експертно-аналітичну систему оцінки умов праці та прогнозування професійних ризиків порушення здоров’я [6, 7]. Впровадження цих розробок сприятиме ефективному вирішенню основних завдань із реформування медичної галузі.

Мета роботи - оцінка впливу умов праці на здоров'я працюючих, структуризація останніх за рівнями впливу умов праці, визначення порядку отримання і шляхів використання даних структуризації для планування заходів збереження здоров'я працюючих у шкідливих умовах (на прикладі гірників вугільної галузі).

\section{Матеріали та методи дослідження}

Дослідження проведено на типових вугільних шахтах із пологим і крутим заляганням вугільних пластів. Чисельність працюючих у підземних умовах складає відповідно 1323 і 951 особа.

Проаналізовані персональні дані 2274 трудових книжок працюючих стосовно їхнього віку, займаних посад і професій, виробничих ділянок і служб, вугільних підприємств, а також дані журналів обліку диспансерних хворих. Професійну захворюваність вивчали за 5 останніх років. За роками в архіві обласної СЕС проаналізовані «Картки обліку профзахворювань (профотруєнь)» гірників, які на момент постановки діагнозу працювали на зазначених шахтах. Персональні дані щодо професійних маршрутів, професійних та інших 
захворювань введені до автоматизованої системи моніторингу впливу умов праці на стан здоров'я працюючих. Сформовані електронні бази даних про стан здоров'я й професійні маршрути гірників. Через автоматизовану систему на кожного працюючого обчислені персональні дані стосовно віку, термінів роботи в контакті з пилом, шумом і вібрацією, зважених у часі за період трудової діяльності рівнів легеневої вентиляції, ступеня перевищення пилом гігієнічного нормативу, накопичених доз понаднормативного впливу на організм виробничого шуму та вібрації, диференційованих за етіологією професійних ризиків порушення здоров'я. Відповідно до правил множення ймовірностей за формулою:

$$
\begin{aligned}
& \text { Risk }_{\text {підсум }}=100 \cdot\left[1-\left(1-\text { Risk }_{\text {пил }}\right) \cdot\right. \\
&\left.\cdot\left(1-\text { Risk }_{\text {шум }}\right) \cdot\left(1-\text { Risk }_{\text {вібр }}\right)\right]
\end{aligned}
$$

де Risk $_{\text {підсум }}$ - ризик сполученого впливу фактоpiв;

Risk $_{\text {пил }}$, Risk шум $_{\text {, Risk }}$ вібр - ризик від впливу пилу, шуму, вібрації окремо розраховували підсумковий професійний ризик у разі сполученого впливу шкідливих виробничих факторів. Захворюваність оцінювали за показниками кількості хворих або випадків захворювань на 1000 працюючих у підземних умовах.

Отримані результати обробляли методами варіаційної статистики.

\section{Результати дослідження та їх обговорення}

На шахті із крутими пластами (КП) вугілля видобувається в очисних вибоях 6 виробничих ділянок на горизонтах 970/1080 м. У 4 вибоях вугілля виймається вручну відбійними молотками (ВМ), в інших двох вибоях - механізовано агрегатами щитовими (АЩ). Проходження гірничих виробок здійснюеться робітниками на 14 виробничих ділянках молотковим i буро-вибуховим способом. Ритмічність і безперервність виробничого процесу з видобутку вугілля та проходження гірничих виробок забезпечують гірники виробничих ділянок із монтажу і демонтажу гірничого обладнання, ремонту гірничих виробок, шахтного транспорту, буро-вибухових робіт та електромеханічної служби. Планові профілактичні роботи щодо знепилювання й дегазації пластів виконують гірники ділянки профілактичних робіт із техніки безпеки. Контроль за безпекою робіт здійснюють спеціалісти ділянки вентиляції та техніки безпеки. У підземних умовах на шахті працюе 951 робітник.
На шахті з похилими пластами вугілля видобувається на горизонтах 475/760 м на двох ділянках у лавах, що обладнані механізованими комплексами. Роботи на прохідницькій ділянці виконуються буровибуховим способом, наділянці гірничо-капітальних робіт - комбайновим. Робочі місця у виробках суттєво обводнені. Процеси виймання і проходження гірничих виробок забезпечують робітники виробничих ділянок із монтажу, демонтажу та ремонту виробничого обладнання, з ремонту гірничих виробок, з конвеєрного і шахтного транспорту, з відведення води, спеціалісти електромеханічної служби та шахтного зв'язку. Робітники ділянки профілактичних робіт із техніки безпеки, ділянки вентиляції та техніки безпеки проводять роботи по знепилюванню і дегазації пластів, контролюють безпеку робіт, що виконуються. Загальна кількість підземних робітників складає 1323 людини.

Різниця в умовах праці працюючих в основному виявляється серед гірників очисних вибоїв, забійників і прохідників через застосуванням на шахтах неоднакових технологій виймання вугілля і проходження виробок. На відміну від шахти з пологими пластами, де вугілля видобувається сучасним способом механізованими комплексами, виймання вугілля на крутих пластах проводиться вручну відбійними молотками (у 4 з 6 вибоях) і супроводжується більш високою запиленістю повітря і рівнями шуму, додатковим впливом на працюючих локальної вібрації. Частково така сама різниця в умовах праці виявляється між робітниками прохідницьких ділянок і ділянки гірничо-капітальних робіт при застосуванні відповідно буро-вибухової і комбайнової технології. То того ж, роботи на шахті із крутими пластами на глибині 1000 м і більше нерідко виконуються в умовах нагріваючого мікроклімату.

На шахті з пологими пластами працюють більш старші і стажовані робітники (табл. 1). Достовірна різниця між показниками віку та стажу роботи гірників у підземних умовах становить відповідно 1,3 і 1,6 року. За персональною оцінкою анамнезу трудової діяльності працюючих гірників шахти з пологими пластами останні зайняті на виконанні більш механізованих робіт, енергомісткість яких значно нижча. За оцінкою аналога енерговитрат легеневої вентиляції розбіжності в рівнях між гірниками шахт хоча і не перевищують $9 \%$, але достовірні на високому рівні надійності $(\leq 7 \mathrm{E}-14)$. Гірники шахти 3 пологими пластами під час роботи зазнають менш 
Вік і стаж роботи гірників та параметри впливу факторів виробничого середовища

\begin{tabular}{|l|c|c|c|}
\hline \multicolumn{1}{|c|}{ Показники } & $\begin{array}{c}\text { ПП } \\
(\mathbf{n = 1 3 2 3 )}\end{array}$ & $\begin{array}{c}\text { KП } \\
(\mathbf{n = 9 5 1 )}\end{array}$ & P \\
\hline Вік, років & 39,0 & 37,7 & 0,0079 \\
\hline Стаж роботи під впливом пилу, років & 14,2 & 12,6 & $7 \mathrm{E}-05$ \\
\hline Легенева вентиляція, м /хв & 0,023 & 0,025 & $7 \mathrm{E}-14$ \\
\hline Перевищення ГДК, разів & 12,8 & 16,1 & $8 \mathrm{E}-08$ \\
\hline Ризик від впливу пилу, \% & 20,6 & 20,4 & 0,852 \\
\hline Стаж роботи під впливом шуму, років & 6,8 & 6,9 & 0,7 \\
\hline Понаднормативний рівень шуму, дБ А & 3,7 & 5,7 & $2 \mathrm{E}-19$ \\
\hline Понаднормативна доза шуму, дБ А & 9,1 & 12,2 & $1 \mathrm{E}-12$ \\
\hline Ризик від впливу шуму, \% & 4,8 & 6,7 & $8 \mathrm{E}-10$ \\
\hline Стаж роботи під впливом вібрації, років & 5,5 & 5,6 & 0,8 \\
\hline Понаднормативний рівень вібрації, дБ А & 1,9 & 3,0 & $2 \mathrm{E}-21$ \\
\hline Понаднормативна доза вібрації, дБ А & 6,3 & 8,3 & $2 \mathrm{E}-08$ \\
\hline Ризик від впливу вібрації, \% & 3,4 & 4,4 & 0,0003 \\
\hline Підсумковий ризик від впливу пилу, шуму, вібрації, \% & 24,6 & 26,7 & 0,076 \\
\hline Доля ризику від впливу пилу, \% & 74,4 & 60,3 & $1 \mathrm{E}-22$ \\
\hline Доля ризику від впливу шуму, \% & 18,0 & 28,8 & $4 \mathrm{E}-15$ \\
\hline Доля ризику від впливу вібрації, \% & 7,6 & 10,8 & $1 \mathrm{E}-12$ \\
\hline
\end{tabular}

вираженого впливу виробничого пилу. Різниця в показниках перевищення пилом ГДК між групами обстежених дорівнюе приблизно 20 \%. На відміну від тривалості дії пилового фактора терміни роботи гірників вугільних шахт під впливом шуму і вібрації майже однакові. Проте, понаднормативні рівні впливу на працюючих шахти із крутими пластами шуму та вібрації вище, ніж в іншій професійній групі, приблизно на 1-2 дБ А, а накопичені понаднормативні дози впливу зазначених факторів вище на 2-3 дБ А.

Результати оцінки професійних ризиків від впливу виробничого пилу, шуму і вібрації не суперечать гігієнічному висновку про відмінності в умовах праці на робочих місцях, що виявлені. Застосування на пластах крутого падіння більш ризиконебезпечних технологій виймання вугілля вручну відбійними молотками та проходження гірничих виробок молотковим і буро-вибуховим способом супроводжуються відповідною структурою професійних ризиків. Доля осіб, що працюють при відсутності професійного ризику впливу пилу на обох шахтах майже однакова. Вона становить 28,3-29,5 \% (рис. 1). При наднизьких рівнях професійних ризиків (до $10 \%$ ) на шахті з пологими пластами працює приблизно 17 \% від загальної кількості гірників. На шахті із крутими пластами при низьких рівнях професійних ризиків працює лише $10 \%$ робітників. При низьких (до 30 \%) i середніх (до 50 \%) рівнях професійних ризиків на шахтах із пологими та крутими вугільними пластами працює більшість підземних робітників, відповідно 40,5 і 50,2 \% від їхнього загального складу. Доля працюючих із високим рівнем професійного ризику (до $70 \%$ ) на обох шахтах майже не відрізняється. Цей показник суттєво зменшується, і не виходить за межі 8,5-8,7 \%. Нарешті, питома вага працюючих із надвисоким професійним ризиком

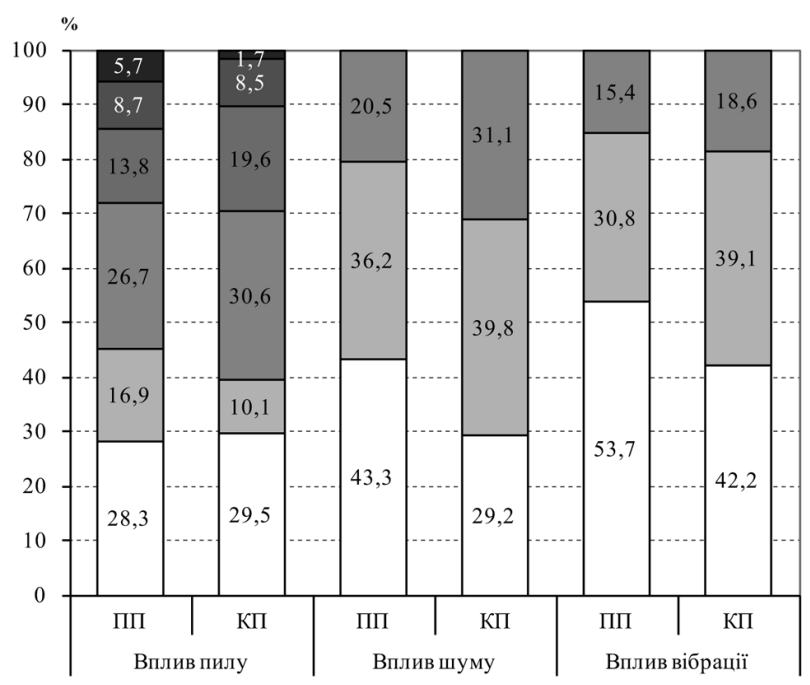

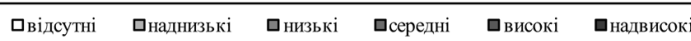

Рис. 1. Структура професійних ризиків гірників. 
(понад 70 \%) - ще менше. У залежності від шахти вона не перевищує $2-6 \%$.

Приблизно 43 і 54 \% робітників шахти з пологими пластами впродовж трудової діяльності не зазнають шкідливого впливу шуму та вібрації. На всіх інших працюючих шум та вібрація впливають на рівнях, що в різному ступені перевищують гранично допустимі. У результаті наднизькі ризики порушення здоров'я від впливу шуму та вібрації реєструються відповідно в 36 і 31 \% працюючих, низькі - у 21 і 15 \% працюючих. На шахтах із крутими пластами число осіб, які не зазнають шкідливого впливу шуму та вібрації, зменшується до 29 i $42 \%$. Наднизькі професійні ризики виявляються майже в 40 \% працюючих, а середні від впливу шуму - майже в кожного третього, вібрації майже в кожного п’ятого підземного робітника.

Структура професійних ризиків у гірників шахт із пологими та крутими пластами формується відповідно до особливостей впливу шкідливих факторів виробничого середовища (табл. 1). На шахтах із крутими пластами у формуванні професійних ризиків зростає вклад шуму та вібрації, зменшується доля пилового фактора. На шахтах із пологими пластами на кожне порушення здоров'я від впливу вібрації очікується приблизно два порушення від впливу шуму та десять - від впливу пилу. На шахтах із крутими пластами співвідношення між очікуваними порушеннями має наступний вигляд: $1: 2-3: 5-6$.

На вугільних шахтах із пологими та крутими пластами серед працюючих у підземних умовах відповідно 181 і 390 осіб перебуває на диспансерному обліку через гострі та хронічні захворювання (табл. 2). Для порівняння, це складає приблизно 14 і 41 \% від загальної кількості робітників підприемства, працюючих у підземних умовах. Кожний сьомий гірник на шахті з пологими пластами та другий, або третій на шахті із крутими пластами хворіють одним і більше захворюваннями. Ізольовані нозологічні форми виявляються приблизно в 75-85\% випадків. У всіх інших хворих одночасно виявляється 2, 3 і більше захворювань. На шахті із крутими пластами цій показник є вищим більш ніж у 1,5 разу.

Серед працюючих на шахті з пологими пластами в структурі захворювань домінують хвороби системи кровообігу та органів травлення. Серед усіх виявлених хвороб зазначені в ізольованій формі разом складають дві третини від загальної кількості. Ще приблизно в 15 \% випадків ці хвороби вияв- ляються в сполученні з іншими. Приблизно 9 \% хворих, що диспансеризовано, мають патологію органів дихання, $9 \%$ - хвороби кістково-м'язової системи та сполучної тканини. Решта працюючих, що диспансеризовано, хворіє на пієлонефрит i сечокам'яну хворобу. У перерахунку на тисячу підземних робітників на захворювання серця та судин страждають приблизно 50 працюючих, органів травлення - 41 працюючий, у сполученні цих захворювань з іншими - 19 працюючих, на захворювання органів дихання - 12 працюючих, кістково-м'язової системи і сполучної тканини - 11 працюючих, сечостатевої системи -2 працюючих. За підрахунком із кожної тисячі підземних робітників вугільної шахти з пологими пластами на диспансерному обліку через гострі та хронічні захворювання перебуває приблизно 137 працюючих.

На шахті із крутими пластами в структурі захворювань гірників, що диспансеризовано, перше місце займають хвороби кістково - м'язової системи та сполучної тканини. Їхня доля становить майже 29 \%, а в сполученні з іншими захворюваннями - більше ніж 47 \% (табл. 2). Практично однаково серед працюючих поширені хвороби системи кровообігу та органів дихання. Разом питома вага цих хвороб складає приблизно 30 \%. На четвертому місці з показником 8,2 \% виявляються хвороби органів травлення. Доля нейроциркуляторної дистонії не перевищуе 5 \%. Приблизно 2 \% працюючих, що диспансеризовано, хворіє на екзему та псоріаз. Внесок інших ізольованих нозологічних форм разом у формування загальної структури захворювань диспансерної групи нижче 3 \% , а сполучених нозологічних форм - 6,5\%. За підрахунком майже 117 працюючих із кожної тисячі страждають на хвороби кістково-м'язової системи та сполучної тканини, 60 і 62 - на хвороби системи дихання та кровообігу, 34 - на захворювання органів травлення, 20 - на нейроциркуляторну дистонію, $10-$ на хвороби шкіри та підшкірної клітковини.

Порівняння показників поширеності захворювань на двох вугільних шахтах свідчить про те, що при відпрацюванні крутих пластів на порядок частіше робітники страждають на патологію кістково -м'язової системи та сполучної тканини, майже в п'ять разів патологію органів дихання, у 30 разів - на сполучену патологію обох класів. До того ж, у гірників шахти із крутими пластами достовірно частіше виявляють варикозну хворобу, периферійну ангіодистонію, нейроциркуляторну дистонію та екзему. 
Таблแщя 2

Захворювання (не професійні) гірників, які перебувають на диспансерному обліку

\begin{tabular}{|c|c|c|c|c|c|c|c|}
\hline \multirow{2}{*}{ Захворювання } & \multicolumn{2}{|c|}{ Число хворих } & \multicolumn{2}{|c|}{ Доля, \% } & \multicolumn{3}{|c|}{$\begin{array}{l}\text { Число хворих на } 1000 \\
\text { підземних робітників }\end{array}$} \\
\hline & $\Pi$ & $\mathbf{K}$ & $\Pi$ & $\mathbf{K}$ & $\Pi$ & $\mathbf{K}$ & $\mathbf{P}$ \\
\hline Хронічний бронхіт & - & 14 & - & 3,59 & - & 14,7 & $\leq 0,001$ \\
\hline Хронічне обструктивне захворювання легенів & 16 & 43 & 8,84 & 11,03 & 12,1 & 45,2 & $\leq 0,001$ \\
\hline Попереково-крижовий радикуліт & - & 67 & - & 17,18 & - & 70,5 & $\leq 0,001$ \\
\hline Остеохондроз попереково-крижового відділу хребта & - & 13 & - & 3,33 & - & 13,7 & $\leq 0,001$ \\
\hline Остеоартроз деформівний & 11 & 30 & 6,08 & 7,69 & 8,3 & 31,5 & $\leq 0,001$ \\
\hline Артрит & 1 & 0 & 0,55 & 0,00 & 0,8 & - & $\geq 0,05$ \\
\hline Хронічний бурсит & - & 1 & - & 0,26 & - & 1,1 & $\geq 0,05$ \\
\hline Подагра & 2 & - & 1,10 & - & 1,5 & - & $\geq 0,05$ \\
\hline Гіпертонічна хвороба & 29 & 10 & 16,02 & 2,56 & 21,9 & 10,5 & $\leq 0,05$ \\
\hline Ішемічна хвороба серця & 7 & 11 & 3,87 & 2,82 & 5,3 & 11,6 & $\geq 0,05$ \\
\hline Гіпертонічна хвороба та ішемічна хвороба серця & 30 & 1 & 16,56 & 0,26 & 22,7 & 1,1 & $\leq 0,001$ \\
\hline Варикозна хвороба & - & 17 & - & 4,36 & - & 17,9 & $\leq 0,001$ \\
\hline Периферична ангіодистонія & - & 20 & - & 5,13 & - & 21,0 & $\leq 0,001$ \\
\hline Хронічний гастрит і гастродуоденіт & 13 & 10 & 7,18 & 2,52 & 9,8 & 10,5 & $\geq 0,05$ \\
\hline Хронічний гепатит & 3 & 2 & 1,56 & 0,51 & 2,3 & 2,1 & $\geq 0,05$ \\
\hline Хронічний холецистит & 2 & 2 & 1,1 & 0,51 & 1,5 & 2,1 & $\geq 0,05$ \\
\hline Хронічний панкреатит & 6 & 8 & 3,31 & 2,05 & 4,5 & 8,4 & $\geq 0,05$ \\
\hline Виразкова хвороба & 23 & 9 & 12,71 & 2,31 & 17,4 & 9,5 & $\geq 0,05$ \\
\hline Інші хвороби органів травлення & 7 & 1 & 3,87 & 0,26 & 5,3 & 1,1 & $\geq 0,05$ \\
\hline Екзема & - & 7 & - & 1,79 & - & 7,4 & $\leq 0,01$ \\
\hline Псоріаз & - & 2 & - & 0,51 & - & 2,1 & $\geq 0,05$ \\
\hline Нейроциркуляторна дистонія & - & 19 & - & 4,87 & - & 20,0 & $\leq 0,001$ \\
\hline Сечокам'яна хвороба & - & 3 & - & 0,77 & - & 3,2 & $\geq 0,05$ \\
\hline Хронічний пієлонефрит & 3 & - & 1,66 & - & 2,3 & - & $\geq 0,05$ \\
\hline Сечокам'яна хвороба, хронічний пієлонефрит & - & 2 & - & 0,51 & - & 2,1 & $\geq 0,05$ \\
\hline Хронічний етмоїдит & - & 1 & - & 0,26 & - & 1,1 & $\geq 0,05$ \\
\hline Хронічний мезотимпаніт & - & 1 & - & 0,26 & - & 1,1 & $\geq 0,05$ \\
\hline Сухота & - & 1 & - & 0,26 & - & 1,1 & $\geq 0,05$ \\
\hline Новоутворення & - & 3 & - & 0,77 & - & 3,2 & $\geq 0,05$ \\
\hline Ізольовані нозологічні форми разом & 153 & 298 & 84,53 & 76,41 & 115,6 & 313,4 & $\leq 0,001$ \\
\hline Сполучені нозологічні форми разом & 28 & 92 & 15,47 & 23,59 & 21,1 & 96,7 & $\leq 0,001$ \\
\hline Усі захворювання разом & 181 & 390 & 100 & 100 & 136,8 & 410,1 & $\leq 0,001$ \\
\hline
\end{tabular}

Доля гірників вугільної шахти з пологими пластами, які страждають попереково-крижовими радикулітами, у загальній структурі професійних захворювань складає 44 \% (табл. 3). Питома вага хвороб органів дихання несуттєво нижче. Їхній внесок становить $41 \%$. Ще $9 \%$ захворювань виникають від впливу на працюючих локальної вібрації. Разом зазначені патологічні форми на 95 \% визначають нозологічну структуру професійної захворюваності вугільного підприємства. В інших $5 \%$ випадках у гірників виявляється два професійні захворювання в різних сполученнях. На шахті із крутими пластами ведучою професійною патологією працюючих є захворювання органів дихання. Пневмоконіоз, хронічний бронхіт і ХОЗЛ разом складають 44 \% від усіх випадків знов виявлених професійних захворювань. Доля захворювань від впливу локальної вібрації менше майже в 2,5 разу. Внесок захворювань на попереково-крижані радикуліти і остеоартроз не перевищує 18 \%. У структурі захворювань гірників шахти із крутими пластами виявляється й інша патологія, яка пов'язана із впливом виробничого шуму, нагріваючого мікроклімату та важкої ручної праці. На долю нейросенсорної приглухуватості, перегрівання та варикозної хвороби припадає $1-2$ \%. Разом зазначена патологія на 85 \% визначає нозологічну структуру професійної захворюваності. Внесок захворювань від впливу одночасно двох і більше шкідливих виробничих факторів складає $15 \%$. 
Таблиця 3

Професійна захворюваність гірників

\begin{tabular}{|c|c|c|c|c|c|c|c|}
\hline \multirow[t]{2}{*}{ Професійні захворювання } & \multicolumn{2}{|c|}{$\begin{array}{l}\text { Число хворих, } \\
\text { що виявлено } \\
\text { за } 5 \text { років } \\
\end{array}$} & \multicolumn{2}{|c|}{ Доля, \% } & \multicolumn{3}{|c|}{$\begin{array}{c}\text { Число хворих, шо виявлено } \\
\text { протягом року, у перерахунку на } \\
1000 \text { підземних робітників }\end{array}$} \\
\hline & П & $\mathbf{K}$ & П & $\mathbf{K}$ & П & $\mathbf{K}$ & $\mathbf{P}$ \\
\hline Пневмоконіоз & 12 & 17 & 16,0 & 4,5 & 1,81 & 3,58 & $\geq 0,05$ \\
\hline Хронічний пиловий бронхіт & 15 & 148 & 20,0 & 39,5 & 2,27 & 31,13 & $\leq 0,001$ \\
\hline $\begin{array}{l}\text { Хронічні обструктивні захворювання } \\
\text { легенів }\end{array}$ & 4 & - & 5,3 & - & 0,60 & - & $\leq 0,05$ \\
\hline Вібраційна хвороба & 7 & 76 & 9,3 & 20,3 & 1,06 & 15,98 & $\leq 0,001$ \\
\hline Попереково-крижовий радикуліт & 33 & 62 & 44,0 & 16,5 & 4,99 & 13,04 & $\leq 0,001$ \\
\hline Остеоартроз & - & 3 & - & 0,8 & - & 0,63 & $\geq 0,05$ \\
\hline Нейросенсорна приглухуватість & - & 6 & - & 1,6 & - & 1,26 & $\leq 0,05$ \\
\hline Перегрівання & - & 5 & - & 1,3 & - & 1,05 & $\leq 0,05$ \\
\hline Варикозна хвороба & - & 1 & - & 0,3 & - & 0,21 & $\geq 0,05$ \\
\hline Ізольовані нозологічні форми разом & 71 & 318 & 94,7 & 84,8 & 10,7 & 66,9 & $\leq 0,001$ \\
\hline Сполучені нозологічні форми разом & 4 & 57 & 5,3 & 15,2 & 0,6 & 12,0 & $\leq 0,001$ \\
\hline Усі захворювання разом & 75 & 375 & 100 & 100 & 11,3 & 78,9 & $\leq 0,001$ \\
\hline
\end{tabular}

Показник виявлення професійних захворювань у гірників шахти із крутими пластами в 7 разів вище, ніж серед працюючих на пологих пластах. Статистика професійної захворюваності за окремими нозологіями переконливо підтверджує такий висновок. Перевага в показнику виявленні професійних захворювань органів дихання сягає 7,4 разу, вібраційної хвороби - 15 разів, попереково-крижових радикулітів - 2,6 разу. Достовірні відмінності аналогічної спрямованості виявляються в гірників двох шахт при порівнянні захворюваності від впливу виробничого шуму і нагріваючого мікроклімату, а також від спільної дії виробничих чинників.

Детальний аналіз поширеності на вугільному підприємстві окремих нозологічних форм патології сприяє розкриттю механізмів впливу умов праці та трудового процесу на здоров'я працюючих, визнанню статусу захворювань, на які страждають гірники, як виробничо зумовлених, обгрунтуванню диференційованих заходів профілактики, оздоровлення, діагностики, лікування та реабілітації (табл. 4). Проведений аналіз свідчить, що ведучою патологією (не професійною) гірників вугільної шахти із крутими пластами є попереково-крижані радикуліти. Остеохондроз хребта й деформівний остеоартроз доповнюють розбіжності в розповсюдженості хвороб цього класу. У перерахунку на тисячу підземних робітників зазначені нозологічні форми виявляються відповідно в 125, 18 і 56 випадках. У працюючих на шахті з пологими пластами зазначена патологія розвивається виключно у вигляді деформівного остеоартроза. При цьому, показник поширеності системної хвороби сполученої тканини втричі нижчий, ніж у гірників іншої шахти. На шахті із крутими пластами хвороби органів дихання виявляються у вигляді хронічного обструктивного захворювання легенів та хронічного бронхіту. Співвідношення між діагнозами ХОЗЛ і хронічний бронхіт складає 1: 0,6. Серед кожної тисячі працюючих хронічна патологія нижніх дихальних шляхів реєструється в 114 випадках. На пологих пластах зазначена патологія виявляється приблизно в 6 разів рідше. До того ж, зовсім відсутні випадки варикозної хвороби та периферичної ангіодистонії. На шахті із крутими пластами поширеність захворювань вен і периферичних судин навпаки становить 65 випадків у перерахунку на 1000 працюючих. Нарешті, показник розповсюдженості нейроциркуляторної дистонії на шахті із крутими пластами сягає 22 випадків. На іншій шахті ця патологія в гірників не виявляється.

Відмінності в показниках професійної захворюваності між гірниками обстежених шахт виявляються більш суттєвими. На відміну від пологих на шахтах із крутим заляганням вугільних пластів захворювання на пневмоконіоз діагностують у 2,4 , хронічний бронхіт і ХОЗЛ - у 12, вібраційну хворобу - у 14, попереково-крижовий радикуліт у 3,1 разу частіше.

Визнання статусу захворювання як виробничо зумовленого базується на логічному тлумаченні об'єктивних даних стосовно причинно-наслідкового зв'язку умов праці з показниками захворюваності гірників. У нашому випадку різним умовам праці 
Захворюваність гірників

\begin{tabular}{|c|c|c|c|c|c|}
\hline \multirow[t]{2}{*}{ Захворювання } & \multicolumn{2}{|c|}{ Число захворювань } & \multicolumn{3}{|c|}{$\begin{array}{c}\text { Число захворювань у перерахунку } \\
\text { на } 1000 \text { підземних робітників }\end{array}$} \\
\hline & $\Pi$ & $\mathbf{K}$ & П & $\mathbf{K}$ & $\mathbf{P}$ \\
\hline \multicolumn{6}{|c|}{ Захворювання (не професійні) гірників, які перебувають на диспансерному обліку } \\
\hline Попереково-крижовий радикуліт & - & 119 & - & 125,1 & $\leq 0,001$ \\
\hline Остеоартроз деформівний & 22 & 53 & 16,6 & 55,7 & $\leq 0,001$ \\
\hline Остеохондроз хребта & - & 17 & - & 17,9 & $\leq 0,001$ \\
\hline Хронічне обструктивне захворювання легенів & 26 & 68 & 19,7 & 71,5 & $\leq 0,001$ \\
\hline Хронічний бронхіт & - & 40 & - & 42,1 & $\leq 0,001$ \\
\hline Варикозна хвороба & - & 21 & - & 22,1 & $\leq 0,001$ \\
\hline Периферична ангіодистонія & - & 41 & - & 43,1 & $\leq 0,001$ \\
\hline Нейроциркуляторна дистонія & - & 21 & - & 22,1 & $\leq 0,001$ \\
\hline \multicolumn{6}{|c|}{ Уперше виявлені протягом року професійні захворювання } \\
\hline Пневмоконіоз & 2,4 & 4,2 & 1,8 & 4,4 & $\leq 0,05$ \\
\hline Хронічний бронхіт & 3 & 38,8 & 2,3 & 40,8 & $\leq 0,001$ \\
\hline Хронічні обструктивні захворювання легенів & 1,4 & - & 1,1 & - & $\leq 0,01$ \\
\hline Вібраційна хвороба & 2,2 & 23 & 1,7 & 24,2 & $\leq 0,001$ \\
\hline Попереково-крижовий радикуліт & 6,8 & 15,2 & 5,1 & 16,0 & $\leq 0,001$ \\
\hline Остеоартроз & - & 0,8 & - & 0,8 & $\leq 0,05$ \\
\hline Нейросенсорна приглухуватість & - & 3,6 & - & 3,8 & $\leq 0,001$ \\
\hline Перегрівання & - & 1 & - & 1,05 & $\leq 0,05$ \\
\hline Варикозна хвороба кінцівок & - & 0,2 & - & 0,21 & $\geq 0,05$ \\
\hline
\end{tabular}

Примітка. *Дані усереднено за результатами виявлення професійних захворювань впродовж останніх 5 років.

відповідають суттеві і достовірні відмінності в показниках захворюваності на радикуліт, остеоартроз і остеохондроз (хвороби периферійної нервової, кістково-м'язової системи і сполученої тканини - ХПНКМС), органів дихання (ХОД), на периферичну ангіодистонію (ПА), нейроциркуляторну дистонію (НЦЛ), варикозну хворобу кінцівок (ВХK). Серед професійних захворювань за локалізацією та мішенню уражень на зазначену патологію схожі хронічний пиловий бронхіт, вібраційна хвороба від впливу локальної вібрації, попереково-крижовий радикуліт, остеоартроз та варикозна хвороба через виконання вручну дуже важких робіт, до того ж, нерідко в незручній позі, перегрівання від впливу тепло-вологого мікроклімату. Зіставлення показників поширеності цих захворювань серед гірників обстежених вугільних підприємств відбиває наявність структурної кореляції між професійними та не професійними захворюваннями (рис. 2). Кількісна оцінка показника відповідності за коефіцієнтом Спірмена становить 0,74. Такі результати можуть бути додатковим аргументом на користь визнання захворювань виробничо зумовленими.

У програмі економічних реформ розділ «Реформа системи охорони здоров'я» передбачає більш ефек- тивне й виключно цільове використання коштів, які виділяються на охорону здоров’я та соціальне забезпечення. Адміністративні та медичні заходи щодо збереження професійного здоров'я як окремих робітників, так і професійних колективів, мають фінансуватися через державний та регіональні бюджети, програми розвитку провідних галузей промисловості і сільського господарства, у тому числі паливно-енергетичного комплексу, Фонд соціального страхування від нечасних випадків на виробництві та профзахворювань. Заходи збереження здоров'я працюючих і виртати на них мають базуватися на даних аналізу медичної, санітарногігієнічної та виробничої інформації стосовно впливу умов праці на здоров'я робітників ризиконебезпечних професій, які надаються за результатами скринінгу професійних ризиків, попередніх та періодичних медичних оглядів, диспансеризації хворих.

Як приклад наведений порядок отримання i використання інформації, що необхідна для обгрунтування заходів збереження здоров'я гірників. На першому етапі для створення групи медичних фахівців, планування обсягів і графіку проведення планового медичного огляду працюючих у шкідливих умовах визначають кількість і поіменний склад осіб, які мають ризики порушення здоров’я від 
199

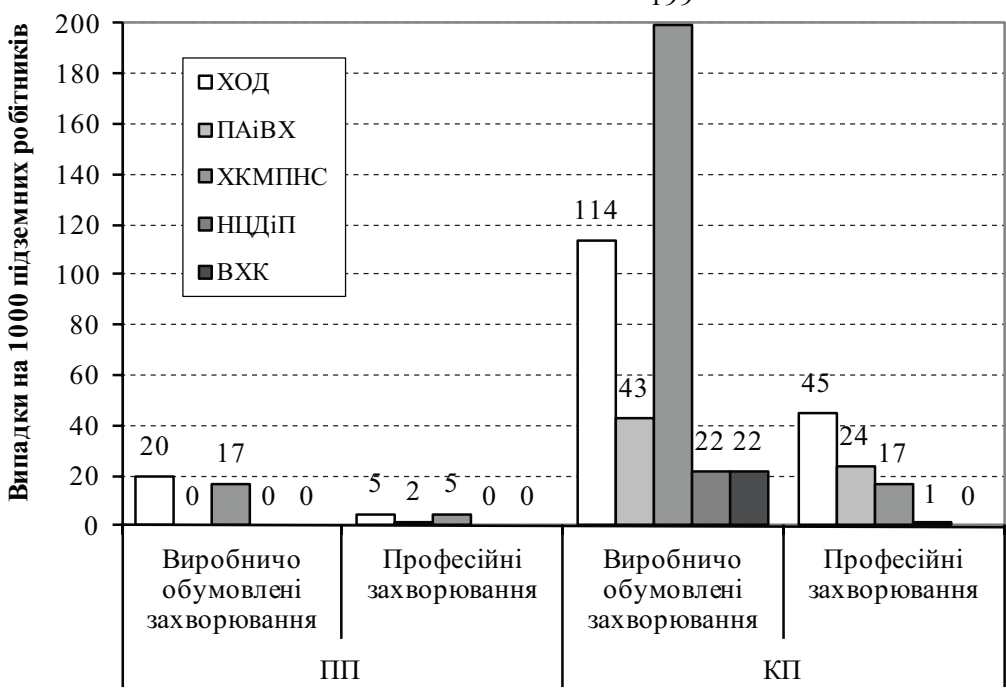

Рис. 2. Виробничо обумовлені та професійні захворювання.
1,7 разу. Через більш молодий і менш стажований склад працюючих на $8 \%$ знижується доля осіб, які зазнають впродовж 10 років і більше фізичного перенапруження.

За результатами медичного огляду гірників було виявлено особи з підозрою на професійні та інші захворювання. До клініки професійних захворювань для постановки остаточного діагнозу було направлено 25 гірників шахти 3 пологими та 113 гірників шахти з крутими пластами. Для виявлення інших захворювань на додаткове обстеження в поліклінічних умовах із тих самих шахт було направлено відповідно 22 і 53 особи. Між медичними спеціалістами вони розподілилися наступним чином: послуг кардіолога потребували відповідно 8 і 10, гастроентеролога -8 і 6 , пульмонологу - 3 i 11 , хірурга 2 i 8 , нефролога - по 1 особі. Крім того, 7 працівників шахти із крутими пластами були направлені до невропатолога, 2 - до дерматолога, по 1 - до фтизіатра і онколога. Після обстеження в клінічних умовах у 15 з 25 гірників шахти з пологими пластами було виявлено професійне захворювання. Серед 113 гірників шахти із крутими пластами професійне захворювання виявлено в 75 випадках.

Таблщц 5

Розподіл працюючих за видами надання медичних послуг

\begin{tabular}{|c|c|c|c|c|c|c|c|c|c|c|c|c|}
\hline \multirow{3}{*}{$\begin{array}{c}\text { Медична } \\
\text { спеціальність }\end{array}$} & \multicolumn{4}{|c|}{ Медичний огляд } & \multicolumn{4}{|c|}{$\begin{array}{c}\text { Обстеження в поліклініці } \\
\text { або клініці (відділенні) } \\
\text { профзахворювань } \\
\end{array}$} & \multicolumn{4}{|c|}{ Диспансерні заходи } \\
\hline & \multicolumn{2}{|c|}{ П } & \multicolumn{2}{|l|}{$\mathbf{K}$} & \multicolumn{2}{|c|}{$\Pi$} & \multicolumn{2}{|c|}{ K } & \multicolumn{2}{|c|}{$\Pi$} & \multicolumn{2}{|c|}{$\mathbf{K}$} \\
\hline & Число & $\%$ & Число & $\%$ & Число & $\%$ & Число & $\%$ & Число & $\%$ & Число & $\%$ \\
\hline Терапевт & 949 & 72 & 669 & 70 & & & & & & & & \\
\hline Невропатолог & 391 & 30 & 481 & 51 & & & 14 & 8 & & & 86 & 18 \\
\hline Отоларинголог & 559 & 42 & 580 & 61 & & & 1 & 1 & & & 2 & 1 \\
\hline Хірург & 459 & 35 & 261 & 27 & 2 & 4 & 7 & 4 & 14 & 7 & 44 & 9 \\
\hline Дерматолог & & & & & & & 2 & 1 & & & 9 & 2 \\
\hline Пульмонолог & & & & & 3 & 7 & 11 & 6 & 16 & 8 & 57 & 12 \\
\hline Кардіолог & & & & & 8 & 17 & 10 & 6 & 66 & 34 & 59 & 13 \\
\hline Гастроентеролог & & & & & 8 & 17 & 6 & 4 & 54 & 28 & 32 & 7 \\
\hline Нефролог & & & & & 1 & 2 & 1 & 1 & 3 & 1 & 5 & 1 \\
\hline Онколог & & & & & & & 1 & 1 & & & 3 & 1 \\
\hline Фтизіатр & & & & & & & & & & & 1 & 0 \\
\hline Ізольовані форми & & & & & 22 & 47 & 53 & 32 & 153 & 78 & 298 & 64 \\
\hline Сполучені форми & & & & & & & & & 28 & 14 & 92 & 20 \\
\hline Профпатолог & & & & & 25 & 53 & 113 & 68 & 15 & 8 & 75 & 16 \\
\hline
\end{tabular}


Під диспансерним наглядом через гострі та хронічні захворювання (не професійні) на шахтах із пологими та крутими пластами перебуває 181 і 390 осіб. За нозологією, що виявлена, на пологих пластах домінують особи, які страждають на серцево-судинну, шлунково-кишкову патологію, патологію печінки та підшлункової залози. Разом вони складають майже дві третини від усіх захворювань. При диспансеризації такі хворі потребують уваги з боку кардіолога та гастроентеролога. Доля захворювань суглобів та легенів не перевищуе $7-8$ \%, нирок -1 \%. Їхне лікування та реабілітація неможливо без участі хірурга, пульмонолога та нефролога. У 14 \% випадків до процесу диспансеризації мають залучатися фахівці із двох і більше спеціальностей. Структура послуг, у яких є потреба в гірників, які диспансеризовані на шахті із крутими пластами, дуже відрізняється від попередньої. Приблизно 18 \% хворих мають користуватися послугами невропатолога, $12-13 \%$ - пульмонолога та кардіолога, 9 \% - хірурга, 7 \% - гастроентеролога. У поодиноких випадках хворі звертатимуться до дерматолога, нефролога, онколога, отоларинголога та фтизіатра. Нарешті, реабілітація кожного п'ятого хворого має відбуватися за участю двох і більше спеціалістів.

Не зосереджуючись на загальних та специфічних для кожної хвороби заходах диспансеризації, слід зазначити особливий підхід до хворих на виробничо зумовлену патологію. Розуміючи, що із часом особи цієї диспансерної групи можуть перейти до групи професійно хворих, дуже важливими заходами збереження їхнього професійного здоров'я $є$ раціональне працевлаштування гірників у працездатного віку та своєчасне переоформлення трудового контракту з пенсіонерами.

Отже, структуризація гірників за рівнями впливу на них умов праці через оцінку професійних ризиків і стану здоров'я забезпечуватиме обгрунтоване планування обсягів, термінів і графіків проведення заходів щодо збереження здоров'я працюючих у шкідливих умовах, підготовку кошторису до цільового фінансування програми диспансеризації в межах окремих галузей, адміністративнотериторіальних утворень і України в цілому.

\section{Література}

1. Медична технологія створення та гігієнічна оцінка баз даних про умови праці гірників вугільних шахт / Современные технологии в медицине труда / [Передерій Г. С., Валуцина В. М., Вержаковський I. I. та ін.].- Донецк, 2009.- С. 34-38.

\section{Висновки}

1. Відмінності на досліджених шахтах виявляються в технологіях видобутку вугілля i проходження виробок, глибині горизонтів, що розробляються. На шахті із крутими пластами роботи в очисних та прохідницьких вибоях здійснюються на глибині 970 і 1080 м застарілими технологіями, переважно молотковою та буро-вибуховою, з низьким рівнем механізації. На пологих пластах в очисних вибоях застосовують вугільні механізовані комплекси, на ділянці гірничо-капітальних робіт комбайнову технологію проходження виробок. Роботи проводяться на глибині 475 і 760 м.

2. Структура та рівні професійних ризиків і захворюваності гірників відбивають ступінь шкідливості та важкості праці. На шахтах із крутими пластами доля осіб, які зазнають шкідливого впливу шуму та вібрації, більше в 1,5-1,7 разу, поширеність виробничо зумовлених та виявлення професійних захворювань вище за всіма нозологічними формами. Різниця в розповсюдженості виробничо зумовлених захворювань кістково м'язової системи та сполучної тканини становить 12 , органів дихання -6 разів. Відмінності аналогічної спрямованості стосуються периферійної ангіодистонії, нейроциркуляторної дистонії та варикозної хвороби. Показники виявлення професійних захворювань органів дихання в гірників шахти 3 крутими пластами вище майже в 9, вібраційної хвороби - у 14, патології периферійної нервової і кістково-м'язової системи та сполученої тканини - у 4 рази. До того ж, у працюючих виявляється професійна приглухуватість, перегріви та варикозна хвороба кінцівок.

3. Дані структуризації гірників за рівнями шкідливого впливу умов праці в результаті оцінки професійних ризиків і стану здоров'я є базою для обгрунтування змісту, обсягів і порядку проведення заходів збереження здоров'я гірників, підготовки кошторису до цільового фінансування програми диспансеризації в межах окремої галузі, адміністративнотериторіальних утворень і України в цілому.

2. Technology of work conditions' and health state of workers monitoring in the system of complex security (SCM) of life and occupational health of miners / G. Perederiy, I. Yaschenko, V. Umanskiy, D. Lastkov [at all].- Donetsk, 2010.- 14 p.

3. Технологія моніторингу умов праці та здоров'я працюючих в системі комплексної безпеки 
життєдіяльності і професійного здоров'я шахтарів / [Уманський В. Я., Передерій Г. С., Ластков Д. О. та ін.] / / Вестник гигиены и эпидемиологии.- 2010.- Т. 14, № 1.- С. 189-194.

4. Удосконалення контролю за безпекою робіт i здоров'ям шахтарів на базі автоматизованої системи комплексної безпеки / [Уманський В. Я., Передерій Г. С., Ластков Д. О. та ін.] // Актуальні питання діагностики та лікування професійних захворювань в Україні.- Кривий ріг, 2010.- С. 72-79.

5. Питання удосконалення державного соціальногігієнічного моніторингу умов праці та стану здоров'я гірників вугільних шахт / [Передерій Г. С., Мухін В. В., Пономаренко А. М., Тімошина Д. П.] // Актуальні питання профілактики, діагностики та лікування професійних захворювань.- Донецьк, 2007.C. $150-156$.

6. Технологія скринінгової оцінки та профілактики професійних ризиків гірників вугільних шахт / [Передерій Г. С., Ластков Д. О., Вєтров С. Ф. та ін.] // Східноєвропейський журнал громадського здоров'я.2011.- № 1.- С. 193-194.

7. Гігієнічний аналіз та оцінка професійної діяльності гірників вугільних шахт за даними профмаршрутів і санітарно-гігієнічного моніторингу умов праці / [Уманський В. Я., Передерій Г. С., Ластков Д. О., Вєтров С. Ф.] / / Український журнал з проблем медицини праці.-2011.- № 1.- С. 12-22.

\section{Передерий Г. С.', Аастков А. О.', Ветров С. Ф.2 2 Партас О. В.' \\ УСОВЕРШЕНСТВОВАНИЕ ПОРЯАКА ОЧЕНКИ И ПРОФИААКТИКИ ВАИЯНИЯ УСАОВИЙ ТРУАА НА ЗАОРОВЬЕ ГОРНОРАБОЧИХ УГОАЬНЫХ ШАХТ}

'Аонешкий нашиональный медишинский университет имени М. Горыкого

${ }^{2}$ Аонешкая областная санитарно-эпимемиологическая станшия

Определены отличия в условиях труда горнорабочих угольных шахт с пологими и крутыми пластами. Показано, что они обусловлены применяемыми технологиями и глубиной разработки угольных горизонтов. Установлено, что и уровни профессиональных рисков и заболеваемости отражают степень вредности и тяжести труда. Представлены результаты структуризации горнорабочих по уровням вредного воздействия условий труда. Приведен порядок получения и пути использования данных структуризации для планирования мер сохранения профессионального здоровья и определения сметы по их осуществлению.

Ключевые слова: горнорабочие, профессиональное здоровье, профилактика

\section{Perederiy G.', Lastkov D.', Vetrov 5. ${ }^{2}$, Partas 0.'}

\section{IMPROVEMENT OF THE ORDER OF ASSESSMENT AND PREVENTION OF THE EFFECT OF WORIK CONDITIONS ON COAL MINERS' HEALTH}

'M. Gorky Donetsk National Medical University

${ }^{2}$ Donetsk Regional Sanitary-Epidemiological Station

The differences in work conditions of coal miners in mines with flat-lying and sharp seams have been determined. It is found that they depend on the used technologies and on the depth of coal horizons development. It is defined that the structure, rates of occupational risks and morbidity point to the degree of work intensity and danger. The results of distribution of miners by levels of harmful effects, caused by work conditions, are given. The order of receiving data and ways of their use in planning actions on occupational health preservation is presented, concerning, also, calculation of the budget for their implementation.

Key words: miners, occupational health, prevention

Надійшла: 16.06 .2011 p.

Контактна особа: Ластков Дмитро Олегович, докт. мед. наук, професор, завідувач кафедри,

Донецький національний медичний університет імені М. Горького, пр. Ілліча, 16, м. Донецьк, 83003.

Тел./ф.: (622) 956-739. E-mail: lastkov.donmu@list.ru 